\section{US-Soviet joint monitoring of nuclear explosion in Nevada}

Washington \& Las Vegas

A HISTORIC step towards a nuclear testban treaty was taken on 17 August when thirteen US and seven Soviet scientists jointly monitored the explosion of a 150-kiloton US nuclear device at the topsecret US Nevada Nuclear Test site.

The event was designed to give scientists from both nations the chance to match their methods of monitoring the size of nuclear explosions. Next month, US scientists will attend a similar test at the Soviet Semipalatinsk nuclear site.

If agreement can be reached on how to measure the size of nuclear explosions, a major impediment to ratification of two treaties limiting the size of nuclear tests will be removed. These are the Test Ban Treaty of 1974 which limited underground explosions to 150 kilotons, and the Peaceful Nuclear Experiments Treaty of 1976.

According to Geneva nuclear test-ban negotiatiors C. Paul Robinson of the United States and Igor Palenykh of the Soviet Union, who were present for the Nevada test, the joint monitoring programme may eventually lead to a comprehensive test-ban treaty.

In the past, the US administration has accused the Soviet Union of breaking the 150-kiloton unratified test-ban limit. The Soviet Union has denied these charges, saying that the seismic monitoring methods it favours show the limit has not been violated. But the US side has argued that only the CORRTEX method it favours will accurately measure the size of nuclear blasts. CORRTEX is very intrusive compared to seismic methods as it involves placing a long cable in a borehole just alongside the shaft in which the nuclear device is detonated and measuring the rate at which the cable is crushed (see Nature 326, 818; 1988).

\section{Boost for shuttle}

\section{Washington}

THE US space shuttle's rocket booster was successfully test-fired on 18 August at Morton Thiokol Inc.'s test facility, clearing the way for the shuttle Discovery to be launched in September or October. In order to test rigorously the redesigned booster's safety features, 14 flaws were deliberately introduced into the booster rocket before the test. These included damage to the $\mathrm{O}$ rings that seal the joints between booster segments. But even with unrealistic levels of damage hot gas did not appear to escape from the joint seals. Accidental escape of hot gas triggered the explosion that destroyed the space shuttle Challenger.

Alun Anderson
The use of CORRTEX inevitably means that Soviet and US scientists have to visit each others' test 'sites. Despite earlier objections to such visits, the Soviet government last year changed its policy and proposed a bomb test exchange in which both sides would use essentially the same CORRTEX techniques.

In the Nevada test, identical cables from the monitoring borehole led to separate US and Soviet instruments. Shortly after the blast, Viktor N. Mikhailov, Soviet team leader at the Nevada Test Site, announced that Soviet instruments had worked and data had been recorded. The room burst into applause.

Raw data gathered on 17 August will be analysed along with information collected at next month's Semipalatinsk test. Only then will be it be clear if Soviet and US instruments are yielding the same results. If the tests prove successful, they are expected to be followed by negotiations over how often each side should allow tests to be monitored. Agreement should make it possible for the Threshold Test Ban Treaty to be ratified.

At the same time as the on-site monitoring was carried out under the official USSoviet agreement, groups of Soviet and US scientists sponsored by the US National Resources Defense Council (NRDC) and the Soviet Academy of Sciences made unofficial off-site measurements using the seismic techniques that NRDC has been pressing the US administration to accept seismic monitoring and has sponsored visits of US experts to the Soviet Union (see Nature 328, 192; 1987). NRDC experts hope that their new results will persuade the US administration that seismic methods yield the same results as on-site monitoring.

Alun Anderson \& Mary Manning

\section{Scientists in trouble}

\section{Las Vegas}

THREE unidentified US geologists will not participate in the Soviet Union's joint verification experiment scheduled for $\mathbf{1 4}$ September at Semipalatinsk after Soviet inspectors discovered unauthorized site samples in their luggage.

The Soviets filed a protest on $25 \mathrm{July}$, but did not proceed with a formal complaint after officials agreed to remove the trio from the experiment. Department of Energy (DoE) officials called the rock, soil and wire samples "souvenirs". DoE sent a team of experts to the Soviet Union to prepare for an unprecedented exchange of data as the United States did for separate nuclear blasts measured by both superpowers.

The US scientists had soil, rocks, barbed wire and a hammer in their luggage. Soviet authorities said the materials violated the terms of an agreement signed by superpower leaders at the Moscow summit.

DoE Nevada Operations Manager Nick Aquilina said after the successful US test on 17 August that the collectors did "something foolish". Mary Manning have been favoured by the Soviet Union.

\section{Landsat keeps an eye on continuing US drought}
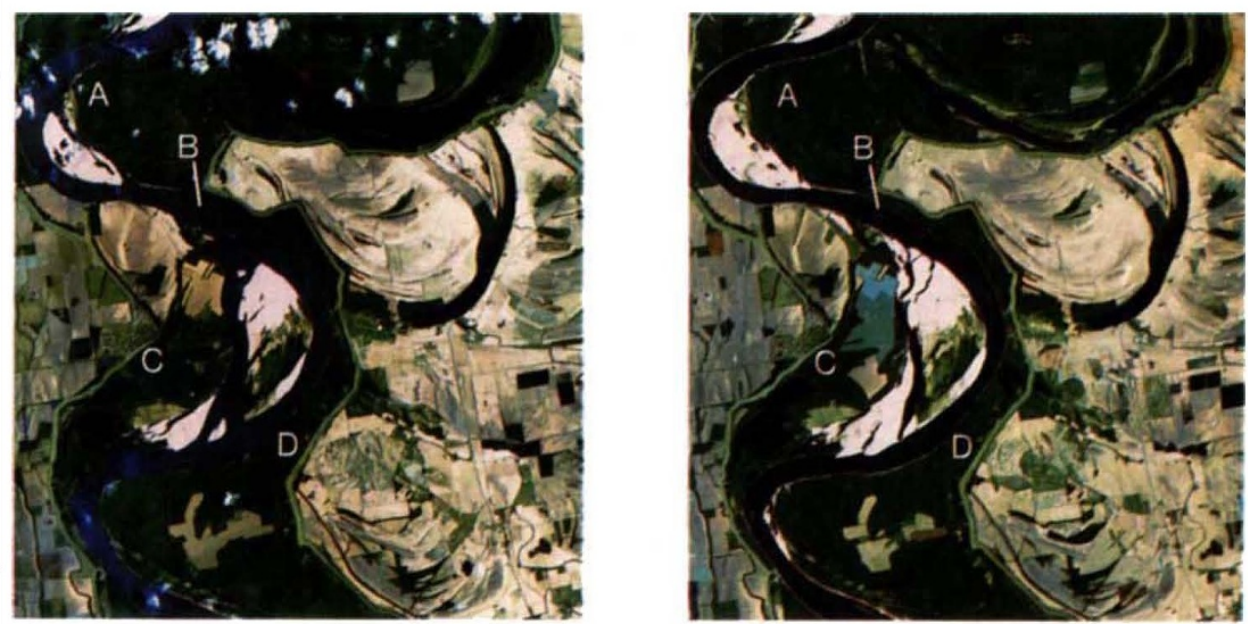

The Mississippi River, three miles north of Greenville during an average year (left, 3 June 1985), when river gauge readings measured 26.8 feet, and on 11 June this year, when gauge readings were at a record low of 12.1 feet. At point $A$ in the images the river has decreased in width by a quarter of a mile, and the water level in the oxbow lake to the right is drastically reduced. In the main water channel $B$, strings of barges can be seen in the 1988 picture, waiting for an increase in water level. At $C$ an increase in size of the large sandbar has closed off some of the river channels just east of Arkansas City. The bright green line $D$ is the system of control dykes. 